\title{
Sønderjydske Veteraner fra Napoleonskrigene.
}

Af Cand. juris. Kaptajn H. E. E. Koch.

Medens vor historiske Litteratur kan opvise righoldige Samlinger af $\mathrm{Breve}$ fra danske K rig s mænd fra de to slesvigske Krige, er det tilsvarende Materiale fra Krigen 1807-14 ikke mere overvældende, end at det vel kan trænge til al den Supplering, det kan faa.

G e $n$ f or e ning e $n$ i 1920 ved Frankrigs og dets Allieredes Bistand mellem Nordslesvig og det ovrige Danmark lægger det desuden nær at ihukomme den Tid, da Danmark 100 Aar før Verdenskrigen var en af Frankrigs sidste Allierede. Det kunde i hvert Fald formodes, at denne Trofasthed i Fortiden ikke har været helt uden Indflydelse paa Begivenhederne i Nutiden. Under alle Omstændigheder er der ved disse vist Efterkommerne af de nordslesvigske Veteraner fra hin Tid en ganske særlig begrundet Retfærdighed, saavist som det gamle Slesvigske Infanteriregiment blandt sine Veteraner tæller det største Antal af dem, der i 1858 blev dekoreret med den Erindringsmedaille, der her nærmere skal omhandles, S a n c t H e le n a-M ed a illen.

Der blev i 1858-59 gennem de danske militære Ministerier uddelt med et rundt Tal hen ved 300 Sanct Helena-Medailler med tilhørende Diplomer i Nordslesvig. Adskillige af dem maa vel findes endnu rundt omkring i Dragkiste- og Kommodeskuffer som en Erindring fra Oldefaders Tid. Kunde disse Linier bidrage til, at lokale historisk Interesserede ved Hjælp af nedenstaaende Billeder og Navnefortegnelsen over Veteranerne fik disse draget frem af Glemselen og forklaret de Efterlevende, hvad der ligger til Grund for denne Eresbevisning, saa vilde maaske en større Glans omstraale den Afdødes Minde, og et Hovedformaal med denne Afhandling vilde være naaet.

I sin sidste Vilje, dikteret paa Sanct Helena i Foraaret 1821, havde Napoleon den Store testamen. 
teret Halvdelen af sin Privatformue stil de Officerer og Soldater, som er tilbage af den franske Hær, der har kæmpet fra 1792 til 1915 for Nationens Are og Uafhængighed «. I god Overensstemmelse med denne Tanke indstifterie hans Brodersøn, Kejser $\mathrm{N}$ a p oI e o n III, da han ønskede ved et særligt Udmærkelsestegn at hædre de Militære, der havde kæmpet under Frankrigs Faner i de store Krige fra 1792 til 1815, ved Dekret af 12. August 1857 en Erindringsmedaille, som under 27. s. M. fik Navnet $\mathrm{Sanct} \mathrm{H}$ elenaMedaille $n$, og som skulde gives til alle Militære, franske som fremmede, af Hær som af Flaade, der havde kæmpet under Frankrigs Faner i de næunte Aar. Den skulde bæres i Knaphullet i et temmelig langt grønt- og rødstribet Baand (se Billedet af Jacob Hansen Kloppenborg forrest i hans Bog "En gammel Soldats Erindringer" 1861); den skulde være af Bronce og paa den ene Side bære Napoleon den Stores Billede, paa den anden Omskriften: Felttogene fra 1792 til 1815 - og Indskriften:

A ses compagnons de gloire

Sa derniére penseé

Ste Héléne 5 mai 1821.

(Til hans Fæller i Hæderen Hans sidste Tanke.)

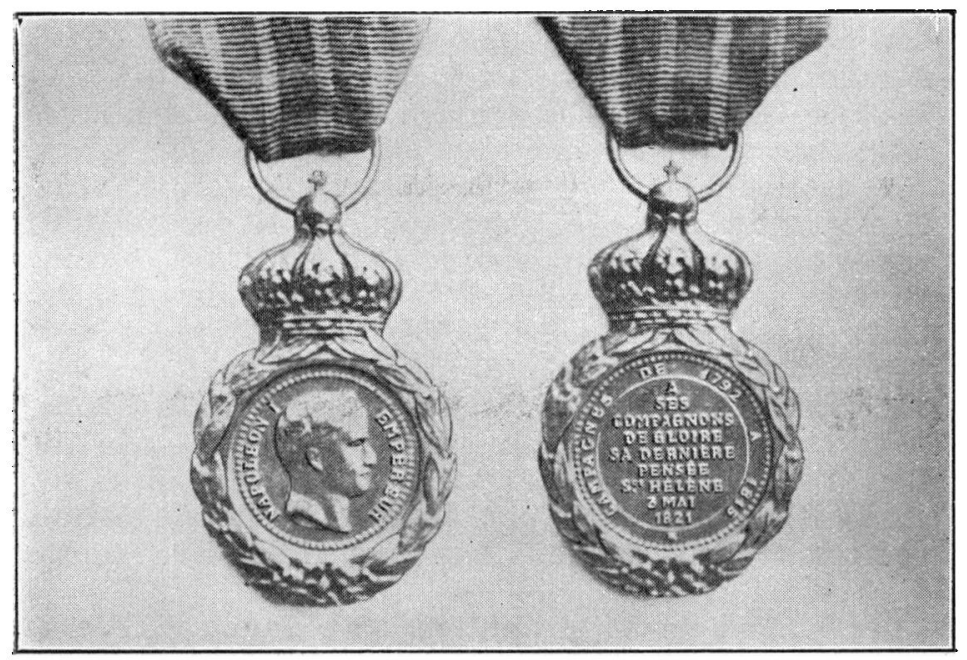

Sanct Helena-Medaillen. 
Da det ved Gennemlæsningen af Veteranernes nedenfor gengivne mest karakteristiske Begæringer om Sanct Helena-Medaillen vil være af Betydning at have de Begivenheder, som de hentyder til, nogenlunde paa rede Haand, skal det her forinden forsages, saa sammentrængt som muligt, at give en fortlobende Sammenkædning af disse smaa og store Enkeltheder fra $S$ ønderjyders Deltagelse i K a m p e ne 1807-14:

Efter at Englænderne i September 1807 havde røvet den danske Flaade, sluttede Danmark den følgende Maaned et Forbund med Frankrig, der vedvarede - mere eller mindre inderligt - til Maj 1813. Napoleon lovede at hjælpe Danmark med at erobre Skaane, og i Marts 1808 paabegyndte et Hjælpekorps af franske og spanske Tropper under Befaling af Marchal Bernadotte, Prins af Pontecorvo, Indrykning i Danmark. Allerede i April fik Bernadotte imidlertid Ordre til at samle Franskmændene i Lejre ved Hamborg, Rendsborg og Flensborg, og kun de spanske Tropper blev spredt over Danmark, hvor de i August s. A. gjorde Oprør og dels blev transporteret til deres Fædreland paa engelske Skibe, dels blev overmandet og ført som Fanger til Frankrig. Med Slutningen af Aaret 1808 forlod ogsaa de øvrige Hjælpetropper Danmark.

I Maj 1809 deltog en dansk Styrke under Befaling af General Ewald $i$ en Ekspedition under Ledelse af den franske (hollandske) Ge ner a l Gratien mod $\mathrm{Stralsund,} \mathrm{hvor} \mathrm{den} \mathrm{preussiske} \mathrm{Fri-}$ skarefører Ferdinand v o n S chill ("Grøw Skeel«, som han kaldes $\mathbf{i}$ "E Bindstouw") holdt til. Byen toges den 31. Maj med stormende Haand, og Schill faldt. De danske Tropper var bl. a. (jfr. nedenstaaende Indledning til Veteranfortegnelsen): Old. Inf. Rgmt. I og II (undtagen Gren. Comp.), Holst. Inf. Rgmt. III, Detachement af Holst. Rytt. Regmt. og et kørende Batteri (Heltzen). I August s. A. ydede Ewald ligeledes bl: a. med Old. Inf. Rgmt. I og II, Holsten III og Halvbatteriet Heltzen Franskmændene Bistand mod Hertugen af Brunsvig O e l s' Friskarer ved Weseren.

Da en stor Del af vor F la a d e s Personale ved Udleveringen i 1807 var bleven overfladig, blev der 
afgivet Bemanding til de 2 franske Linieskibe "Pultusk " og "Dantzig", der i Maj 1808 tilligemed 6 andre Skibe udlagdes $p$ a a $\mathrm{S}$ h el d e n under fransk Flag. Snart efter blev den bekendte Admiral J o o s t va n Dockum Chef for »Pultusk«, og i 1811 blev der yderligere afgivet Bemanding til Krigsskibene "Dalmate" og "Albanais". Afgivelserne varede til Foraaret 1813.

I August 1809 foretog Englænderne en mægtig Ekspedition mod Scheldedeltaet for at tilintetgøre den der stationerede franske Flaade. Allerede den 11. August var de ud for F or t e t B a th (paa Østpynten af Zuid-Beveland), og den franske Flaade maatte trække sig bag en forberedt Barriére mellem Lillo og Liefkenshoek; men dermed standsede Englændernes

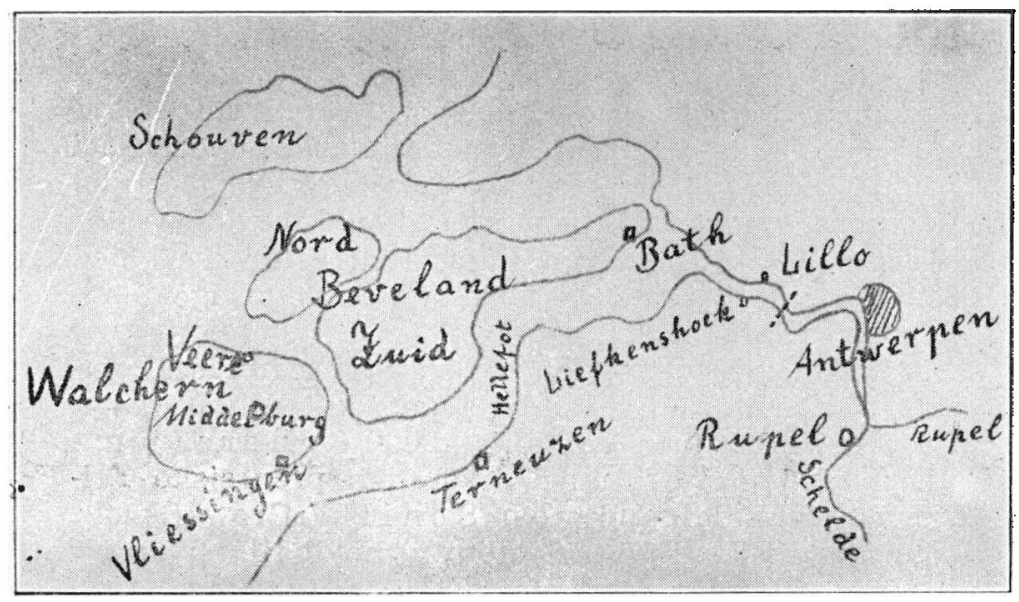

Offensiv, dels paa Grund af svigtende Samarbejde mellem Hær og Flaade, dels paa Grund af frygtelig Marskfeber blandt de engelske Besætninger. I November $\mathbf{s}$. A. forberedte Franskmændene en Offensiv, bl. a. formeredes 4 Divisioner af Kanonbrigger og andre Smaafartøjer, af hvilke den ene Division fik dansk Besætning. Den 8. December fandt en mindre Kamp Sted, men Englænderne var da alt i Opbrud.

Napoleon inspicerede Flaaden 1810 og $1812 \mathrm{og}$ var meget tilfreds med de danske Søfolk. 
De danske Troppebevægelser $7 / 3 \quad 1812$ - ${ }^{10 / 7}$ 1813 afspejler Frederik VI's Vankelmodighed: om han turde holde fast ved Napoleon eller ej. ${ }^{34} / 2$ 1813 rykker bl. a. nogle Kompagnier af old. Inf. Rgmt. til Hjælp for Franskmændene i $\mathrm{Ha} \mathrm{m} \mathrm{borg,}$ $1{ }_{\mathrm{s}} \mathrm{s}$. A. forsvarer 2 Kompagnier Oldenborg sammen med russiske og tyske Tropper Øen Wilhelmsburg mellem Hamborg og Harburg mod Franskmændene, og den 30. s. M. stilles bl. a. 21/2 Bataillon af Oldenborgske, 1 af Slesvigske og 1 af Holstenske Regiment, 2 Esc. Jydske Dragoner og 2 af Holst. Ryttere til Raadighed for den franske Højestbefalende i Nordvesttyskland, $\mathrm{Mar} \mathrm{ch}$ a $\mathrm{l} \mathrm{D}$ a v o u t, Prins af $\mathrm{Eck}$ m ü h l. Den ${ }^{4 / 6}-{ }^{16} / \mathrm{s}$ var der Vaabenstilstand.

Den 10. Juli sluttedes et stærkere Forbund med Frankrig, hvorved Danmark forpligtede sig til at erklære Sverrig, Rusland og Preussen Krig 24 Timer efter Vaabenstilistandens Ud/løb, forstærke Divisianen i Nordtyskland og til Elbens Forsvar stille. 20 Kanonbaade.

De danske Tropper, der sammen med 3 franske Divisioner indgik i Prinsen af Eckmühls Korps, fik Navnet A u xiliaircorpset og kommanderedes af Prins Frederik af $\mathrm{Hessen,} \mathrm{Frederik} \mathrm{VI's} \mathrm{Svo-}$ ger. Efter Vaabenstilstandens Ophør ansatte Davout den franske General l'A llemand ved Auxiliaircorpset. I Korpset indgik hovedsagelig følgende Afdelinger: Batterierne Gerstenberg, Koye, Friis og Gönner - Jydske Rgmt. lette Dragoner - Fyenske do. - Holstenske Rytter Rgmt. - Fyenske Inf. Rgmt. I og II - 3. Jydske Inf. Rgmt. I - Oldenborgske Inf. Rgmt. I, II og IV samt Jægercomp. III - Slesvigske Inf. Rgmt. I og II - Holstenske Inf. Rgmt. III og IV - Slesvigske Jæger Corps II.

Den 17. Aug. begyndte Fremrykningen mod Øst, ug samme Dag havde l'Allemands Styrke, hvori Holstenske Rytter Rgmt. indgik, et Sammenstad med en Trop Kosakker ved Mölln. I de følgende Dage fortsattes Marchen mod Øst til Schwerin, der besattes den 23. om Aftenen, efter at Kaptajn Pristrophs Jægere af Slesv. Inf. Rgmt. samme Dag ved Wit t e nb u r g havde haft et livligt, men ublodigt Sammenstød med Kosakkerne. Hovedkorpset slog nu forelobig Lejr ved Schwerin, medens l'Allemand sendtes 
videre til Wismar, hvorfra han den 22 . fortsatte mod Rostock. Dette forte den 28., da Holst. Rytt. Rgmt. marcherede i Spidsen af hans Hovedstyrke, til et Sammenstad ved Retschow, ca. 2 Mil vest for Ro. stock. Efter at l'Allemand gennem denne Kamp havde indhøstet tilstrækkelige Efterretninger om de fjendtlige Styrker, gik han den 29. Aug. tilbage til Wismar.

I Stillingen $\mathrm{S}$ c h w e $\mathrm{r}$ i $\mathrm{n}-\mathrm{W}$ is $\mathrm{m}$ a $\mathrm{r}$ forblev Armékorpset, til der den 2. Sept. kom Melding om, at den direkte mod Berlin fremsendte Hær var fuldstændig slaaet af de Allieredes Nordhær. Prinsen af Eckmühl gik da tilbage til en Stilling mellem Ratzeburg og Mölln; samme Dag forefaldt en smuk Rytterfægtning ved $G$ a d e bus ch.

L'Allemands Brigade gik den 3. Sept. tilbage til Lübèck, forfulgt af det fjendtlige Rytteri, der den 4 . Sept. om Morgenen fik Held til at overfalde en Feltvagt af Holst. Rytt. Rgmt. ved Das a u. Chefen saaredes dødeligt, desuden mistede Eskadronen sin Estandart, 1 dræbt, 18 saarede, 30 fangne Ryttere og 40 Heste.

I R a t z e b org - Stillingen forblev Korpset fra den $3 / 9-13 / 11$, ideligt skærmydslende med Fjenden. Den 7. Okt. foretog denne saaledes et kraftigt Fremstød mod Stillingen ved $W$ eis ser $\mathrm{H}$ ir s c h, ved hvilken Lejlighed bl. a. Pristrophs Jægere af Slesv. Inf. Rgmt. atter kæmpede tappert. Ligeledes deltog Slesvig I i Rekognosceringsfægtningen ved $\mathrm{K}$ og e $\mathrm{l}$ M ø l l e den 18. Okt.

Den 16. - 18. Okt. tabte Napoleon Folkeslaget ved Leipzig, og da han under Tilbagegangen naaede paa Højde med Davout, maatte denne for ikke at blive omklamret følge Bevægelsen. Den 13. Nov. gik hans Armékorps tilbage til en Stilling bag $\mathrm{S}$ te ck $\mathrm{n}$ it zfloden med venstre Fløj støttet til Lübeck. Mod denne Stilling rykkede Kronprinsen af Sverige forhen Marchal Bernadotte, nu Karl Johan - frem med overlegne Kræfter. Davout turde ikke oppebie ham ved Stecknitz, men besluttede at koncentrere de 3 iranske Divisioner ved Hamborg og holde denne By for at dække Napoleons venstre Flanke, medens Frederik af Hessen skulde gaa mod Nord for at dække Hertugdømmierne. Adskillels e n mellem 
de danske og de franske Vaabenfæller fandt Sted $\mathbf{i}$ de første Dage af December; dog forblev l'Allemand personlig og et polsk Lansener Rgmt. ved Auxiliaircorpset lige til Fredsslutningen.

Karl Johan lod en Fjerdedel af sin Styrke observere Hamborg og ilede efter Auxiliaircorpset med sine Hovedkræfter. Den 4. Dec. udmærkede Slesv. Inf. Rgmt. sig i "en overordentlig brillant Affaire" ved Boden. Den 7. var Rytteriets Dag paa den gamle Valplads ved $B$ ornhøved, hvor den forreste svenske Rytterdivision under General Sköldebrand forte et Angreb ind paa l'Allemands Arriéregarde. Efter denne Fægtning samlede Prinsen af Hessen sit Korps til Kiel, og Natten til den 10. Dec. bivouakerede (!) alt i klingrende Frost 2 Mil vest for Kiel. Samtidig var imidlertid Forfølgerne naaet saa langt mod Nord, at deres forreste Tropper stod mellem Kiel og Rendsborg.

Den 10. Dec. slog Prins Frederik af Hessen sig da ved $S$ e hested efter en Rrkke fortrinlige Angreb af alle Vaabenarter med Bravour igennem disse Fjender "aa kam walhollen in te Rensborre", hvor hian holdt Stand til Fredsslutningen.

G l ü c k s t a ‘d belejredes fra den 12. Dec.; den 1. Jan. 1814 begyndte Svenskerne et vedholdende Bombardement, der varede flere Døgn og førte til Fæstningens Overgivelse den 5. Jan.

Den 14. Jan. 1814 sluttedes Freden i Kiel.

Hermed var Alliancen med Frankrig til Ende.

For Læsere, der maatte ønske at trænge dybere ind $i$ de ovenfor skitserede Begivenheder, skal anføres følgende benyttede trykte Kilder:

O. Vaupell: Den dansk-norske Hærs Historie. II. Kbh. 1876. Meddelelser fra Krigsarkiverne. Udgivne af Generalstaben. I-IX. Kbh. 1883-1902.

F. L. von Bardenfleth: Stormen paa Stralsund. Kbh. 1846.

F. J. Schaldemose: Reiser og Eventyr i fremmede Lande.

I. Kbh. 1826.

C. F. Wandel: Søkrigen i de dansk-norske Farvande 1807 -14. Kbh. 1915.

O. Lütken: De Danske paa Schelden 1808-09. Kbh. 1885 og 1809-13. Kbh. 1888.

O. Bauditz: Blicherske Soldaterhistorier. "Danske Studier" 1921. S. $49-65$ og 1927 S. $93-95$. 
T. Bræstrup: Geheimeconferensraad C. J. C. Bræstrups efterladte Papirer fra 1813-14. Kbh. 1894.

A. Stille: Striden vid Bornhöft .. Lund. 1913.

H. F. Feddersen: Tagebuch eines dänischen Soldaten 1812 -13 . Tondern. 1817.

Dekretet af 12. Aug. 1857 om Sanct Helena-Medaillen vakte snart efter sin Fremkomst Røre viden om, se saaledes i $" D$ a n n e virk e Notitser den ${ }^{15} / \%$, ${ }^{2 k}{ }_{n,}^{20} / 0,1 / 10,30 / 11$ (jfr. senere Aarhus Amtstidende for ${ }^{21}, 58$.).

Den franske Minister i København, Adolphe D oté z a c, der havde været her fra 1840, gjorde alt, for at saa mange Berettigede, som muligt, kunde opnaa Udmærkelsen, og fik bl. a. flere Gange Fristen for Indsendelse af Begæring om Medaillen forlænget.

Fra Sømændene, der jo havde tjent under fransk Flag paa Schelden, indkom de første Begæringer allerede i September 1857 til Marineministeriet. Derimod kunde Landkrigsmændene, der i Nordtyskland havde kæmpet under deres egne Faner, først opnaa Dekorationen, efter at det den 26. Nov. var meddelt, at sdet til at begrunde denne Berettigelse er tilstrækkeligt, at vedkommende .... har tjent med Tropper, som have forholdt sig til de franske Arméer som allierede eller som Auxiliair-Tropper. De kongelige Indersaatter, som i Henhold hertil maatte ansee sig for berettigede .... ville bidrage til Sagens hurtige Ordning .... ved snarest muligt at henvende sig enten til Udenrigsministeriet eller, forsaavidt deres Krav støttes paa tilstedeværende officielle Dokumenter, umiddelbart til det keiserl. franske Gesandtskab i Kjøbenhavn." Disse sidste Henvendelser or ikke behandlede i nærværende Afhandling; de opbevares nu alle i Ministère des affaires étrangères (service des archives), quai d'Orsay, Paris.

Hvad de danske Myndigheders Bistand ved Opnaaelsen af Medaillen angaar, da synes de ikke alle at have været lige interesserede i Sagen eller i hvert Fald at have grebet den synderlig praktisk an. Bekendtgørelserne fremkom sparsomt og lidet iøjnefallende i Dagspressen, rent bortset fra, at det Publikum, de henvendte sig til, næppe var avislæsende i 
videre Udstrækning. Som Følge heraf kom adskillige utvivlsomt berettigede for sent med deres Andragende. Der var dog ogsaa adskillige Amtmænd og Herredsfogeder, der viste sig forstaaende overfor Ansogerne, og navnlig skal det siges til de nordslesrigske Sog n e prosters Ros, at de i stort Antal udførte et omfattende Arbejde for at skaffe disse gamle Mennesker denne Anerkendelse paa deres Livs Aften.

Medens de fra Søværnets Veteraner indkomne Begæringer saa godt som alle o pbevares i Marineministeriets Arkiv i Rigsarkivet blandt Sekretariats- og Kommandokontorets ovrige indkomne Skrivelser, er de til Krigsministeriet indkomne Begæringer saa godt som alle udskilte og samlede i en Pakke, som beror i Hærens Arkiv under "Særlige Sager" (Løbe-Nr. 9). Sammesteds findes et af undertegnede udarbejdet $S$ e d d e l reg is t e r over samtlige Ansøgere og Dekorerede, der er noget udførligere, end det nedenfor aftrykte. Saavel der, som i en i Tidsskrift for Søvæsen 1929 S. 140-145 meddelt, meget udførlig Fortegnelse, findes angivet vedkommende Begærings Indgangsnummer i Marineministeriets Registratur.

De nedenfor benyttede Amtsbetegnelser er de i 1858 brugte; og Afhandlingen omfatter Sognene indtil daværende Flensborg og Tønder Amters Sydgrænse.

Medens saa godt som alle Befalingsmændene har skrevet deres Ansøgninger selv, gælder dette - forstaaeligt nok - de færreste af de Menige. Det overvejende Antal har dikteret eller paa anden Maade faaet ført i Pennen og har saa selv underskrevet, nogle "med ført Pen«. Endelig skriver et ikke ringe Antal pr. Fuldmægtig, oftest Sognepræsten.

Den ${ }^{21}{ }_{110} 1858$ meddeles det officielt, at $\mathrm{Hr}$. Dotézac har bemærket, "at Uddelingen af St. Helenamedaillen nu definitivt vil blive standset «; og der blev derfor ikke taget Hensyn til Andragender, der indkom efter den 16. Nov. 1858. Hvad Grunden kan have været til, at der overhovedet blev' sat en Tidsfrist, er ikke let at faa Øje paa; man skulde mene, at det havide været retfærdigere, saaledes som Praksis har været her i Landet med Erindringsmedaillerne for de slesvigske Krige, overhovedet ikke at sætte nogen Tidsgrænse, 
men at give Medaillen til enhver, der begærede den, naar hans Berettigelse kunde dokumenteres. Der er derfor heller ikke fundet mindste Betænkelighed ved at lade Veteranfortegnelsen omfatte samtlige Ansøgere, idet de udekorerede saa godt som alle er blevet udelukkede, enten fordi deres Begæring er kommen for sent, eller fordi deres iøvrigt hæderlige Krigsdeltagelse ikke berettigede netop til denne Udmærkelse.

Nedenfor følger nogle karakteristiske Gengivelser af Uddrag af enkelte Veteraners Begæringer, ordnede amtsvis, saaledes som (som nævnt) Amterne var i 1858, Da Officererne ikke kan forudsættes at have haft speciel Tilknytning til de enkelte Amter, er deres Begæringer ikke gengivne her; en Del af dem findes trykt i Militært Tidsskrift: Tillægshæfte til Nr. $4 / 1929$ Sp. $10-12$.

Hvilke nulevende Afdelinger, der repræsenterer de i Uddragene nævnte Regimenter og Corps, er der gjort Rede for senere i Indledningen til Veteranfortegnelsen.

\section{Haderslev Amt.}

Skipper og Borger i Haderslev Christian Fritzschler:

I min tidlige Ungdom valgte jeg Søfarten til min Leve- og Næringsvej.

Da nu i Krigen med England, i dette Aarhundredes første og andet Decennium, Søfarten for en stor Del standsede, traf det sig, at jeg, da i Aaret 1808 ,den franske General Bernadotte, Prins af Pontecorvo, var her i Haderslev med et fransk Armeecorps, var uden Employ. Jeg lod mig derfor af Chefen ved det herværende franske Hospital og Feltapotek, Louis Duboi, engagere til at gøre Tjeneste ved Depotet og tillige til at være hans Tjener; fulgte om Efteraaret (1808) med Armeen til Hamborg og forblev. der Vinteren over i min Śtilling, og da 1809 Krigen med Østrig udbrød, fulgte jeg Armeen, dels i samme Egenskab som Tjener, dels som Tjenestgørende ved Bagagen. Omsider naaede vi Sanct Bilden, hvor vi forblev i nogen Tid, kom senere til Wien, hvor Opholdet ogsaa varede i længere Tid. Efter at Armeeafdelingen, hvorved jeg gjorde Tjeneste, havde forladt Wien, 
kom vi til at tage Ophold ved en lille By ved Navn Broock i Nærheden af Pressburg, hvor der udenfor var en stor fransk Lejr. Her forblev jeg i 2 Maaneder; fik derpaa Ordre at vende tilbage til Wien, hvor jeg paa Grund af en svær Sygdom bragtes paa Hospitalet. Da jeg var bleven helbredt igen, blev jeg atter ansat som Tjenstgørende ved Hospitalet og Feltapoteket i Klosterneuburg hos Duboi's Efterfølger Dudanjou, følgelig i min forrige Egenskab, og kom derefter med dette i Aaret 1810 tilbage til Lübeck, hvor jeg fik Tilladelse til at vende hjem til mit Fædreland.

Efter at jeg nu igen havde opholdt mig i nogen Tid her i min Fødeby, blev jeg, der stod i Sørullen og var søtjenestpligtig, i Aaret 1811 paa Sesessionen udskreven til Matrostjeneste paa den franske Flaade; kom ombord paa Linieskibet Dalmatien under den danske Søofficer Mosins Kommando, der i de 13 Maaneder, jeg tjente paa dette Linieskib, for det meste laa paa Rheden af Vliesingen. Dernæst blev jeg tillige med flere andre under Løjtnant v. Askehous Kommando kommanderet til Antwerpen, hvor vi taklede en Brigg, med hvilken vi dernæst sejlede til Helfoetfluys og fik der Station paa Rheden;.dernæst gjorde vi Brandvagt ved Corè ved Indsejlingen ti] Revieret. Endelig kom vi (1813) ombord paa Linieskibet Pultusk under den danske Admiral v. Dockums Kommando; og med hans Mandskabstransport kom jeg igen til Kjøbenhavn, hvor jeg paa Skytsprammen ved Kastrup og Prøvestensbatteri gjorde Tjeneste under Kommandørerne Lemming og $v$. Thunen, indtil 1814 Freden blev sluttet.« ....

Aldersrentenyder Mikke l La us e n i Ostorp By, Taps Sogn, havde lignende Oplevelser paa Schelden: "I en Søtræfning var han med at uddrive Englanderne af Bats, og senere var han ombord paa een af de henved 300 Kanonbrigger, som angreb og fordrev Englænderne fra Vlissingen mellem Jul og Nytaar 1809, idet den Canonbrig, hvorpaa han befandt sig, førtes af en dansk Lieutenant Recke". (Jfr. "De Danske paa Schelden 1809-13«, S. 69-70.)

Sognepræsten i Hoptrup fremfører sit Bysbarn, efternævnte .Inderstes, mere haandgribelige Ønske: "M a d Freberg er en brav og hæderlig gam- 
mel Mand, og saafremt Forholdene tilstede det, maa han anbefales til at erholde bemeldte Medaille eller, hvad han hellere onsker, Aqvivalent derfor." - Han fik Medaillen.

Kaadner $\mathrm{H}$ a n $\mathrm{s}$ Dock w il e $\mathrm{r}$ paa Gaansager Hede i Vodder Sogn har nogle forkerte Datoer og Aarstal, men ellers en smuk Karriére: "1809, den 29. Maj, tjente jeg under Lieutenant Heltzens kjorende Batteri ved Stralsund; 1812 den 16de December deeltog jeg under Kapitain Gerstenbergs kjørende Batteri i Affairen ved Bornhöved, og 18. December ved Sehestedt."

Rasm us Ha n sen (Fillerup) i Haderslev tillader sig at ". .anføre: at jeg i Aaret 1812 ved Sessionen blev udskreven til Tjeneste ved det Holstenske Rytter-Regiment og madte ved sammes UnderviisningsSkole i Haderslev d. 1. Januar 1813. Efter Underviisningstidens Udlob blev jeg ansat i bemeldte Regiments 2den Eskadron, som dengang laae i Grotensee i Holsteen. Ved nævnte Regiment og Eskadron har jeg gjort Tjeneste overalt, hvor samme var til Tjeneste, navnlig blandt andet i Trittau, i Affairen ved Mølln, Bornhøved, i Slaget ved Sehested og saa fremdeles, til min Hjempermittering fandt Sted, efter aflagt Mønstring, i Aaret 1817."

Ped er Pedersen (Fløystrup) paa Drendrup Mark i Ødis Sogn blev som staaende ved samme Regiment, men ".... ved den \&de Escadron commanderet at marschere til bemeldte Regiment i Nærheden af Hamborg, hvorfra der marscheredes til det Mecklenborgske og navnlig til Rostock, og derefter kom man til Dassau, hvor der forefaldt en Fægtning, hvorved jeg med Flere blev taget til Fange, ligesom at vi samtlige bleve førte til Stralsund og derefter først erholdt vor Frihed ved Fredslutningen 1813....

Pensionist Peter Seni us Andersen i Hoptrup: "Efterat have gjennemgaaet Skolen paa Fal. ster, kom vi i April 1813 til Kiel og strax derpaa til Altona. Da derpaa strax efter de Franske gave sig til at beskyde Hamborg, rykkede den danske Armee ud, og vi besatte Staden for en Deel førend de Franske rykkede derifd, og vendte derpaa tilbage til Altona. Kort Tid derefter marscherede vi til Lübeck og bleve lagte i Quarteer strax derved i Byen Stockels- 
dorf under den indtraadte Vaabenstilstand. Efter henved et Par Maaneders Forløb blev jeg med noget Mandskab af vort Regiment commanderet til Travemünde for at gjøre Tjeneste for de Franske, der havide besat Byen. Kort Tid efter fik vi Danske Ordre til at drage til den danske Armee, og vi naaede den ved Schwerin. Den franske Armee laa lige ved den og handlede i Forening med den, og saavidt jeg veed stod begge Armeer under Overcommando af Prindsen af Eckmühl, som var de Franskes General. Her rykkede de Allierede ind paa os, hvorfor vi retirerede til Gadebusch", (Medd. f. Kr. Ark. VII. 160-61; Bræstrup 119), "hvor en Fægtning forefaldt, og sloge omsider Leir ved Ratzeburg. Hele Tiden vare de Franske med os og bleve der liggende hos os 10 à 12 Uger. Først henimod Slutningen af Aaret skiltes de fra os og droge til Hamborg, medens vi droge op gjennem Holsten og efter Slaget ved Sehestedt, hvor ogsaa jeg var med, ind i Rendsborg, hvor vi bleve til Freden sluttedes.

Da vi slog Leir ved Ratzeburg, fik jeg et Stød af en Pallisade, der vel en Tidlang ikke voldte mig videre Men, men som siden, da vi kom i Roe, havde slemme Følger og senere har gjort mig til en Krøbling. $1815 \mathrm{blev}$ jeg forflyttet til Altonaer Grenadeerjægere og Aar 1816 var jeg med dem til Frankrig, hvor jeg blev syg og utjenstdygtig blev sendt hjem.

1820 brød min Sygdom op igjen og 1821 fik jeg.en lille Pension af Krigshospitalskassen....

Hans Hansen Fabrien i Ørsted, Oxenvad S.: "For at vise min Værdighed til bemeldte Medaille tillader jeg mig underdanigst at oplyse, at jeg i Aarene $1808-1813$ i December har tjent med franske Tropper og i Forening med dem under General L'Allemand været i flere Slag, f. Ex. ved Wittenberg i Mecklenburg, Wittenhertz, Kugelmølle og flere, ligesom jeg og endnu bærer Mærker paa mit Legeme af Saar i disse Slag. Under Tjenesten stod jeg ved Slesvigske" Regiments Jægercomp. Nr. 161 "og fik den 1ste April $1815 \mathrm{~min}$ hæderlige Afsked. Min Capitain Pristroph gav mig endog en egenhændig skreven Attest om, at jeg fortjente Dannebrogskorset, men desværre denne Attest er forkommet."

L a u e E b b e s e i Haderslev: "Skjøndt den un- 
derdanigst Undertegnede ikke er istand til at producere mit Afskedsbeviis, idet dette er bortkommet under mit Fangenskab i Rendsborg, hvorhen jeg for min Danskhed i Aaret 1848 blev ført af Fjenden, saa vover jeg dog .....

\section{Aabenraa Amt.}

Hans Jørgensen i Lambjerg Skov: "Jeg er født her paa Als i Aaret 1783 og blev i Aaret 1800 udskreven til Tjeneste, men blev stoppet i Trondhjem 1801. 1807 blev jeg antaget til Opvagter ved Darstofte (?) og Fjammos [ved Østerholm, Egen S.] paa Nordkysten af Als. 1808 blev jeg udskreven i Transport paa Briggen "det gode Haab" ved Holtenau, og 1810 i Norge. 1811 blev jeg udskreven til Tjeneste som fuldbefaren Mand paa det franske Linieskib Dalmate under Kommando af Captain Mossin og Volf ved Vlissingen paa den hollandske Kyst. Her avancerede jeg saa til Styrmandsmat og siden til Kabelrum Skejmand og kom i Aaret 1813 tilbage til Tønningen, hvor jeg gjorde Tjeneste paa Vagtskibet som Quarteermester, indtil den russiske Armée kom ind i Landet; blev jeg af dem tagen til Fange. Senere har jeg faret til Koffardis som Styrmand paa Østersøen og Middelhavet indtil 1848, da jeg blev antaget som Skovopsynsmand under Augustenborg Skovdistrikt."

P o u l P o u l se n (Basse) i Løit fortsætter, hvor han slap, efter Hjemkomsten fra Scheldeflaaden: "Derefter blev jeg Quarteermester paa den danske Kanonbaad "Christian von Glückstadt" (Chefen Capitain-Lieutenant "Christopher Johan Frederik" Hedemann), hvorfra jeg ofte blev udkommanderet til Smaafartøjer og blandt andet en Gang til som Skipper at hjælpe til at føre de franske Soldater fra Haarburg til St. Paulli imellem Altona og Hamburg “ (jfr. Wandel S. 455 og Medd. f. Kr. Ark. VI. 29). "Den nævnte Kanonbaad havde Station paa Elben “ (den er nævnt hos Wandel S. 460). "- Under Glückstadts Belejring og Bombardement var jeg ansat som $\mathrm{KKa}-$ noncommandeur paa en af de danske Skanser."

Om Pe ter Nis e n B ond e se n, Inderste-Aftægtsmand i Bovrup, beretter Sognepræsten i Varnæs, at han "... har tjent i det Slesvigske Regiment til Fods...., dengang dette Regiment 1813 var allieret 
med den franske Armee i Hamborg, Lybeck, Leiren ved Schwerin og Ratzeborg. Da han derfra igjen kom til Hamborg, blev han syg der, men kom siden med til Kiel,-hvor han blev tagen til Fange af de Svenske og faldt i Fangenskab i 3 Maaneder, af hvilken Aarsag han ikke var med ved Sehestedt."

Inderste $\mathrm{H}$ a $\mathrm{n} \mathrm{S} \mathrm{T}$ h a y e $\mathrm{n}$ i Traasbøl, Felsted Sogn, er det gaaet som ovenfor Laue Ebbesen: Sognepræsten skriver, at "Hans Afskedsbevis, hvori det bevidnedes, at han havde tjent vel, var udstedt 1823 , men blev ham i Aaret 1848 frataget af Tyskerne."

\section{Tender Amt.}

Mathias Jensen Petersen $i$ Draved Skovfogedbolig pr. Løgum Kloster er lidt uheldig med Bogstaveringen, men Krigsdeltagelsen i 1813 er god nok: "samme Aar udtoges vi 15,000 Mand som Auxiliær Tropper for de franske, deltog som saadan i Fægtningerne ved Wittenberg, Gadebusch, Gronspode (4 Batailloner), Wittenhesch og Sehested, hvor Prins Frederik og Lallemand commanderede."

Jens Thomsen af Keitum paa Sild "kom i Maj Maaned 1808 med en kgl. Transport paa 42 Mand fra Triest om Bord paa det Kejserlige Franske LinieSkib Pulstock; efter omtrent 9 Dages Forløb blev jeg med flere andre forsat til Linie-Skibet Dantzick og tjente der circa 3 Aar som Halvbefaren." Fra Linieskibet Danzig blev han, ifølge et i Anledning af Ansøgningen optaget Tingvidne, paa een Gang, han mener i Aaret 1809, udkommanderet om Bord paa en Brigg, under Kommando af Løjtnant Søderberg, og paa dette Skib gjorde han en Bataille med mod Englænderne for Batz. "Derefter blev jeg Hovmester hos Officererne, til vi den 10. April 1813 drog derfra, med Lieutenant Sandholt, som Oppasser, til udenfor Flensborgs Port. Han rejste til Jylland, og jeg til Kjøbenhavn i Maj. Dette kan de endnu maaske levende Officerer bevidne, maaske Tuxen o. a."

\section{Flensborg Amt.}

Skibstømrer af Mariæ Sagn i Flensborg P e ter $\mathrm{H}$ a n s e $\mathrm{n}$ Hollä $\mathrm{n}$ de $\mathrm{r}$ indtraadte $\mathrm{i}$ Tjenesten 1808 "og maatte straks ved Faaborg gøre Bataillen med 2 engelske Kutterbrigs med. Derfra i Eftersommeren 
til Nyborg, senere til Kjøbenhavn, Helsingør og 1812 til Ulvshale paa Møen, derfra til Kjøbenhavn og permitteret hjem, hvor jeg indtraf 3 Dage før Sessionen. Paa Sessionen blev jeg som befaren Mand igen udtaget til som Medlem af Hjælpetropperne« osv. (Jfr. om Bataillen ved Faaborg C. F. Wandels anf. Værk S. $119-20$.)

Afskediget Sergent og Overbetjent i Flensborg Michael Rasmussen, der iøvrigt ses at have efterladt sig en $D$ a $g$ bo $g$, beretter:

"Undertegnede, som endnu i sin høie Alder sætter $\sin$ Ere og Stolthed i, ikke alene at have kæmpet for, men endog været fangen og saaret i Kampen for Napoleon den Store, vover $i$ den Anledning at indgive denne sin allerunderdanigste Ansøgning, for, saar fremt han maatte befindes værdig dertil, at blive benaadet med den hæderfulde St. Helene Medaille...

I Aaret 1813, da Napoleon den Store, svigtet af de andre Nationer, endnu fandt en trofast Bundsforvandt i det lille Danmark, marscherede ovennæunte Fyenske Infanteri Regiment til Lübeck, hvor vi gjorde Tjeneste sammen med Franskmændene. I en af de dengang hyppigt forefaldende Skjærmydsler blev Undertegnede mellem Wismar og Schwerin tagen til Fange, men undveg efter 8 Dages Fangenskab Fjenden og kom igjen til Regimentets Leir ved Ratzeburg. Da de franske Vaaben i Aaret 1813 bleve trængte tilbage, trak vi os tilbage til Hertugdømmet Holsteen, hvor Undertegnede under den franske General Lallemand deltog i Slaget ved Sehested og blev saaret...."

For Peter Christian Sommer fortæller Sognepræsten: "I det første Aar (1808) var han menig Liniesoldat, $i$ det andet gjorde han Tjeneste som Un. derofficer, medens hans Afdeling « (Slesv. Jæg. Cps. II) "havde Kystvagt ved Bülk og Dänisch-Nienhof ved Kielerfjorden. I sine 5 sidste Tjenesteaar var han Oppasser for Sekondlieutenant Vilh. Jansen (fra Segeberg). Han forklarer fremdeles" (overensstemmende med M. f. K. A. VIII 107), "at da Tropperne efter at have opgivet Lybæk, som de havde besat, trak sig tilbage ad Rensborg til, havde man glemt at give Ordre til Jægerkorpsets 1ste og 2det Kompagni, samt et Kompagni af en anden Afdeling, at disse $3 \mathrm{Kom}-$ 
pagnier derfor fandt Broerne over Ejderkanalen afbrudte, og at han selv personlig havde Fortjeneste af Tilvejebringelsen af en Overgang ved Levensau (hvor 2 medhavende Kanoner maatte kastes i Kanalen). Derefter var han tilstede under Træfningen ved Sehestedt, hvor han i en Hulvej« (det er Vejen fra Sehested til Osterrade-Broen, M. f. K. A. VIII. 114) "blev reden ned af vore Dragoner efter et mislykket Angreb af disse; "den lille" General Lallemand udførte derefter et afgørende heldigt Rytterangreb."

"Hvis det ikke allerede maatte være for sildigt, ønske følgende, der i Bov og Omegn ere tilbage af Heltene fra Sehested og Bornhøved, som altsaa have hort til med Frankrige Allierede Hjælpekorpser, at modtage St. Helenamedaillen af den franske Keiser, og vove ved mig i saa Henseende at bede sig anbefalede til Excellencens Høie Naade og Anbefaling: «(her opføres 18 Veteraner, hvoriblandt som Nr...) ».. 13. $S ø r$ en $H$ ans en $K$ ragelund nu ved Slukefter, Hanved Sogn, født i Kragelund, Aarhuus Amt, var Feltdegn« (jfr. Feltpræsten Kristoffer Nyholms Optegnelser. Kbh. 1897. S 109-10 og Pastor Strøms Breve i "Museum" 1890 S. 630 og 635) "ved det Holstenske Rytter-Regiment (Oberstlt. v. Stemann, Ritmester v. Segethi, Premierlieutnt. v. Abramowitz) ....

Om foranstaaende Mandskab kan jeg o. fid. pastor, bevidne, at det ifølge de foreviste Attester ikke kan være nogen Tvivl underkastet, at enhver af dem har været med i hiint Felttog, der fartes paa hiin Tid, da den danske Armee var allieret med den franske. Det er mig tillige en Glæde at bevidne, at de $i$ deres Alderdom ere ligesaa agtværdige Mænd, som de $1813 \mathrm{og}$ foregaaende og paafølgende Aar udviste Tapperhed, hvisaarsag jeg tillader mig at anbefale deres allerunderdanigste Bøn om St. Helena-Medaillen paa det bedste og underdanigste.

$$
\text { P. Hansen, Dr. phil. }
$$

Sognepræst til Bov Menighed pr. Flensborg."

Efterstaaende Fortegnelse over Veteranerne er noget mindre udførlig end Seddelregisteret i Hærens Arkiv, bl. a. er udeladt adskillige Oplysninger om Fødselsdag og Fødested, Udskrivningsaar og Lægd, Fægtninger, hvori Veteranen har deltaget, m. m. 


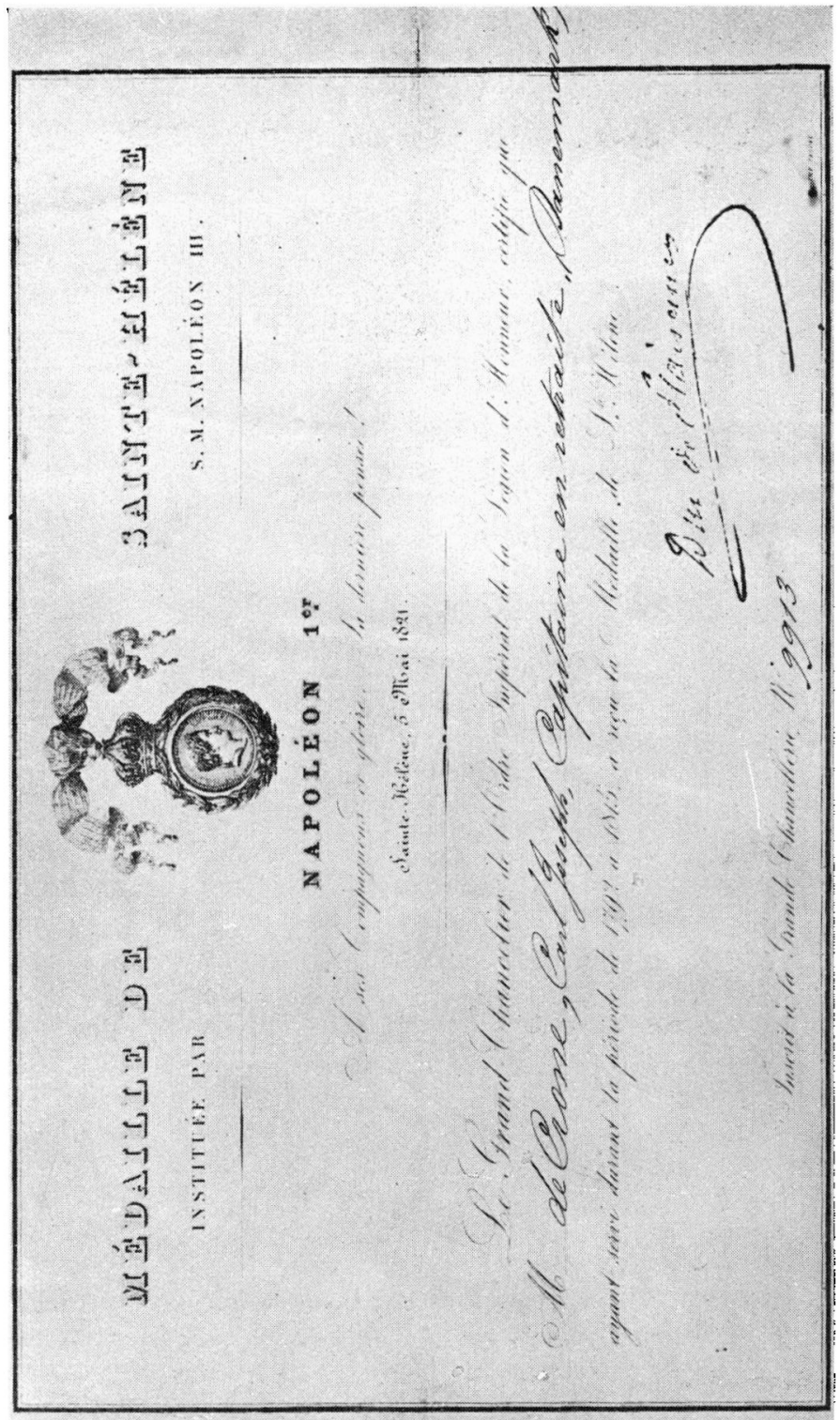


Hvis en Mand er kaldt ved et "-sen" Navn med efterfølgende Stednavn, findes han, hvis han har været Menig, under "-sen «-Navnet, hvis han har tjent som fast Underofficer, under Stednavnet. En énkelt utidssvarende Civilbetegnelse er moderniseret (til "Aldersrentenyder").

Det tør ikke ventes, at der findes en Begæring fra hver eneste Veteran; nogle er f. Eks. indstillede paa Fælleslister, oftest fra vedkommende Sognepræst.

I Forkortelsen af Veteranens militære Betegnelse betyder den første Angivelse Regiment, det vedføjede Romertal Bataillon ved Fodfolket, den næste Kompagni eller Escadron, og den sidste Stam-Nummer. Altsaa: Sl. J. C. - II - 1-155 betyder Slesvigske Jæger Corps - II Bataillon - 1. Compagni - Nr. 155; Holst. R. R. - 4 - 91 betyder Holstenske Rytter Regiment - 4 . Escadron - Nr. 91. Det bemærkes, at Numrene 1-13 besattes med Underofficerer (i Aldersorden) og Spillemænd, og at en Corporal i de Tider var fast Underofficer

I Vaupell II findes kortelig meddelt de enkelte Regimenters Historie. Desuden foreligger der større eller mindre Regimentshistorier for saa godt som alle endnu levende Afdelinger, der er oprettet før 1842 .

Følgende Forkortelser er benyttet:

F. I. R. Fyenske Infanteri Regiment (12. Batl.).

F. R. 1. D. Fyenske Regiment lette Dragoner (3. Dr. Rgmt.).

Gr. Grenadeercompagniet.

Holst. I. R. Holstenske Infanteri Regiment (15. Batl.).

Holst. R. R. Holstenske Rytter Regiment.

Jæg. Jægercompagniet.

2. J. I. R. 2. Jydske Infanteri Regiment (9. Batl.).

3. J. I. R. 3. Jydske Infanteri Regiment (11. Batl.).

J. R. 1. D. Jydske Regiment lette Dragoner (5. Dr. Rgmt.).

J. Sk. C. Jydske Skarpskytter Corps (nedlagt 1816; se Vaupell 1I. 712.).

L. R. 1. D. Livregiment lette Dragoner (gamle 2. Dr. Rgmt., nedlagt 1865 .).

L. R. R. Livregiment Ryttere (1. Di. Rgmt., nedlagt 1856.).

Old. I. R. Oldenborgske Infanteri Regiment (16. Batl.).

Sl. 1. R. Slesvigske Infanteri Regiment (13. Batl.). 
Sl. J. C. Slesvigske Jæger Corps (senere 21. Batl.).

De Navne, der er trukket lidt ind til højre, er Navnene paa dem, der af en eller anden Grund ikke har faaet Medaillen.

Aaskod, Hans Jørgen. Sl. I. R. Arbejdsmand, Arnum, Haderslev A.

Andersen (Wandrup), Jens. F. I. R. - II - 2-141. Rødding, Haderslev A.

Andersen, Peter Senius. Sl. I. R. - II - 7 - 58. Pensionist, Hoptrup, Haderslev A.

Andersen, Rasmus. Holst. R. R. Haderslev.

Andresen, Hans. Batt. Gerstenberg - 12 - 156. Husum.

Andresen, Niss. Sl. I. R. -1-76. Harrislev, Hanved S., Flensborg A.

Appel, Gottfred. Sl. I. R. - 1 -. Indsidder, Galsted, Haderslev A.

Beier, Niels Peter Kjellesen. Sl. I. R. -3-115. Gabel, Nustrup S., Haderslev A.

Beier, Niels Tjellesen. Sl. I. R. - Gr. -. Kaadner, Allerup Mark, Haderslev A.

Berg, Jes Jessen. Batt. Gönner, Stykkusk Nr. 21. Inderste, Felsted Mark, Aabenraa A.

Bertelsen, Laust. Sl. I. R. - Jæg.-87. Arbejdsmand, Arrild, Haderslev A.

Bjørnsen, Peder. Sl. I. R. Gaardmand, Lyshøj i Husby S., Flensborg A.

Boisen, Hans Christensen, SI. I. R. Aldersrentenyder, Arnum, Haderslev A.

Boll, Carl Christoph. Holst. R. R. Escadronschirurg. Læge (Krigsraad og afsk. Bataillonschirurg), Haderslev.

Bondesen, Peter Nissen. Sl. I. R. - 3-128. Inderste-Aftægtsmand, Bovrup, Varnas S. Aabenraa A.

Borg, Andreas Andersen. Sl. I. R. - 8-80. Aftægtsmand, Branderup, Haderslev A.

Brambsen, Peder. Sl. I. R. Arbejdsmand, Vonsbæk, Haderslev A.

Brodersen, Hans. Sl. I. R. Inderste, Satrup, Aabenraa Amt.

Bruhn, Hans. Sl. I. R. - 7-42. Selskjær, Gram Herred, Haderslev A.

Bryde (Seggelund), Hans. F. I. R. 7-29. Steenskro, Haderslev A.'

v. Bülow, Magnus Lützow. 3. J. I. R. Premierlt. Afsk. Major, Flensborg. 
Børglum, Hans. SI. I. R. - 7-122. Skovby, Vedsted S., Haderslev A.

Bøttger, Poul Clausen. Søindrulleret af Slesvigs Distrikt. Løit ved Aabenraa.

Carlsen (Christensen), Georg Friedrich. Sl. I, R. - 8-20. Aftægtsinderste, Igen, Aabenraa A.

Christensen (Holm), Anders. Sl. I. R. - 1 - 137. Indsidder, Vellerup Mark, Haderslev A.

Christensen, Hans. Sl. I. R. -6-131. Boelsmand, Igen, Als, Aabenraa A.

Christensen (Haistrup), Hans. Sl. I. R. -1-108. Aftægtsmand, Raad, Haderslev A.

Christensen, Jens. Sl. I. R. $-6(1)-46$ (76). Stenderup, Haderslev A.

Christensen, Johannes. Sl. I. R. -5-128. Aldersientenyder, Mellerup, Haderslev A.

Christensen, Rasmus. Sl. I. R. Parcellist, Søbygaardsmark, Ærø.

Christiansen, Bøye. F. I. R. - 7-66. Terkelsbøl, Tinglev S., Flensborg A.

Christiansen, Frederik. SI. I. R. - Gr.-69. Aftrgtsmand, Felsted, Aabenraa A.

Christiansen, Hans. Sl. I. R. -5-. Iolm, Nordborg S., Aabenraa A.

Christiansen, Johan(nes). Sl. I. R. - 3-153. Husmand, Westerterp, Nørreløgum S., Aabenraa A.

Christiansen, Peter. Sl. I. R. - 7-147. Ellund, Hanved S., Flensborg A.

Christophersen, Claus Hansen. Sl. I. R. Skrav S., Haderslev A.

Clausen, Frederik. Old. I. R. - 5 -. Snedker og Inderste, Bodum i Løjt S., Aabenraa A.

Clausen, Friedrich. Halvbefaren af Slesvigs Distrikt Nr. 1111. Sømand, Flensborg.

Clausen, Jess. Sl. I. R. - 1-71. Aftæegtsmand, Kjestrup By, Hoptrup S., Haderslev A.

Clausen, Johan. Sl. I. R. - Gr.-47. Sophiedal. Tinglev S., Flensborg A.

Clausen, Johan Christopher. Sl. I. R. Kaadbo, Rise pr. Ærøskjøbing, Ærø.

Clausen, Niels. Sl. I. R. - Gr. - 86. Skrydstrup S., Haderslev A.

Diederichsen, Diederich. Batt. Friis-11. Hyllerup, Hanved S., Flensborg A. 
Diederichsen, Johan. Batt. Friis. Langbjerg, Hanved S., Flensborg A.

Dinesen, Rasmus. Sl. I. R. - Gr. - 101. Sillerup, Haderslev A. Dircksen, Carsten. Batt. Koye-13-185. Husum.

Dockweiler, IIans. Batt. Heltzen og Gerstenberg-12-85. Kaadner, Gaansager Hede, Vodder S., Haderslev A. Uransfeld, Mads Clausen. Sl. I. R. Kastrup, Gram S., Haderslev A.

Døstrup, Christian Hansen Wæger. F. I. R. - I - Underoff. Pens. Sergeant og Regimentsskriver, Østergasse, Skjærbæk S., Haderslev A.

Ebbesen, Laue. Sl. I. R. -5 - 18. Haderslev.

Elling, Jørgen Nielsen. Søindrulleret, Nørre Lygum.

Engelsen, Niss. Sl. I. R. - Gr. - 161. Lle Solt, Flensborg A.

Eriksen, Hans Peter. Sl. I. R. - Jæg. - 100. Boelsmand, Olde, Rise, Erø.

Eriksen, Thomas Jacobsen. Sl. I. R. -4-156. Bedsted, Aabenraa A.

Fabrien, Hans Hansen. Sl. I. R. - Jæg. - 161. Ørsted, Oxenvad S., Haderslev $A$.

Fessel, Peter Christian. Liv R. R. - 4-4. Klasselottericollecteur i Flensborg.

Franck, Jens Iversen. Old. I. R. - Jag. - 58. Endrupskov, Gram S., Haderslev A.

Frantzen, Frantz Nicolai. Søindrulleret af Slesvigs Distrikt Nr. 387. Kattry, Notmark S., Nordborg A.

Frantzen, Hans Nicolai. Søindrulleret af Slesvigs Distrikt Nr. 396. Kattry, Notmark S., Nordborg A.

Fredberg, Mads. Sl. I. R. -6-153. Inderste, Hoptrup Kirkeby, Haderslev A.

Friedrichsen, Friedrich. SI. I. R. -5-135. Kjøbingmark ved Nordborg, Aabenraa A.

Fritzel, Heinrich. Old. I. R. - IV-3-10. Murersvend, Flensborg.

Fritzschler, Christian. Søindrulleret af Slesvigs Distrikt Nr. 19. Skipper og Borger i Haderslev.

Goeg, Anton. Sl. I. R. - 3-. Over Jersdal, Vedsted S., Haderslev A.

Grau, Christen Jessen. Sl. I. R.-5-. Holm, Nordborg S., Aabenraa A.

Greysen, Lauritz. Sl. I. R.-7-14. Endrupskov, Gram S., Haderslev A.

Gubi, Martin. SI. I. R. - III - Jæg. - 144. Bedsted, Aabenraa A. 
Gubi, Peter Madsen. F. I. R. - Gr.-98. Arbejdsmand, Beftoft, Haderslev A.

Haag, Hans. Sl. I. R. - 2-22. Aftægtsmand, Guderup, Igen S., Aabenraa A.

Hansen, Anders. Sl. 1. R. -7-91. Arbejdsmand, Skjærbæk, Haderslev A.

Hansen (Skipper), Christian. Lysabildskov paa Als.

Hansen (Nøraae), Gjerulf. Holst. R. R. - 4-35. Meilbye, Lintrup S., Haderslev A.

Hansen, Hans. Sl. I. R. - III - 3-37. Roager, Haderslev A,

Hansen (Lausen), IIans. F. I. R. - Gr.-. Maibølgaard, Aabenraa $\mathrm{A}$.

Hansen, Hinrich. 12. Art. Comp. -64. Timmersig, Flensborg A.

Hansen, Hans Christian. Stykkusk i Art. Holm Skov, Igen S. (Als).

Hansen, Hans Madsen. Sl. I. R. Indsidder, Tranderup, Erø.

Hansen, Jens. Sl. I. R. Aldersrentenyder, Arnum, Haderslev A.

Hansen, Jørgen. Sl. I. R.-1-57. Nyhuus, Bov S., Flensborg A.

Hansen, Lorenz. Sl. I. R. - 3 -. Husejer, Lygumkloster, Aabenraa $A$.

Hansen, Ludvig. Old. I. R. - III - Jæg. -. Kors i Adelby S., Flensborg A.

Hansen, Mads Peter. Sl. I. R. Borger og Høker i Senderborg, Aabenraa A.

Hansen, Niels. Batt. Lohse. Bov, Flensborg A.

Hansen, Niels. J. Sk. C. - I-1-40. Skrav S., Haderslev A.

Hansen, Peder. F. I. R. - Gr.-73. Husmand i Wilslef ved Ribe.

IIansen, Peter. Liv R. 1. D. - 2 -. Arbejdsmand, Skjærbæk, Haderslev $\mathbf{A}$.

Hansen, Peter. Sl. I. R. -1-30. Kromand og Gaardmand i Uk, Aabenraa A.

Hansen (Elsmark), Peter. Hertuginde Louise Augustas Livjægercorps - 2 - 75. Aftægtsmand, Bovrup i Varnæs S., Aabenraa A.

Hansen, Rasmus. F. I. R. - Jæg. - 56. Arbejdsmand, Ring tved, Maugstrup S., Haderslev A.

Hansen (Fillerup), Rasmus. Holst. R. R.-2-91. Haderslev.

Hansen (Kjær), Rasmus. Sl. I. R. - 3 - 119. Boelsmand, Varnæs, Aabenraa A. 
Hansen, Søren. Sl. I. IR.-4-88. Aldersrentenyder, Gram, Haderslev A.

Hansen (Kragelund), Søren. Holst. R. R. - 2 - Feltdegn 144. Ved Slukefter, Hanved S., Flensborg A.

Iansen. Truels. Liv R. R.-1-93. Hjulmand i Nørbye, Vilstrup, Haderslev A.

Henningsen, Hans. Batt. Kjerulf el. Koye-16-67 (76). Aftægtsmand, Hivilbjerg, Lle Solt Sogn, Flensborg A.

Henningsen, Lorenz. Sl. I. R. Frøskjøbing, Erø.

llenningsen, Mathias. Sl. I. R. - 7 -. Indsidder, Gremmerup, Husby S., Flensborg A.

Henningsen, Peter. Sl. I. R. Aftægtsmand i Grumtofte, Flensborg A.

Herregaard, Thomas. SI. I. R. - Jag. - 61. Aastrup, Haderslev A.

IIinrichsen. Johan Hinrich. Hertuginde Louise Augustas Livjægercorps. Gaardmand, Uk, Aabenraa A.

Holländer, Peter Hansen. Søindrulleret af Slesvigs Distrikt Nr. 29. Skibstømrer, Mariæ Sogn, Flensborg.

Holm (Tømmerbye), Niels Hansen. F. I. R. - II - 7 - Hygum, Haderslev A.

Hundrup, Niels Peter. Sl. I. R. - III -1-148. Hjulmand i Lygumkloster, Tønder A.

Iversen, Morten. Sl. I. R. - III - 3 . Skrave S., Haderslev A.

Iversen, Niels Matthiesen. F. I. R. - Gr.-63. Aventoft, Tonder A.

Jacobsen, Carl Ferdinand. Helbefaren af Slesvigs Distrikt Nr. 300 . Flensborg.

Jacobsen (Iøøerg), Jørgen. F. I. R. - 1 -. Rødding, Haderslev $A$.

Jacobsen, Jacob Nielsen. Sl. I. R. -3-100. Halk, Haderslev $A$.

Jacobsen, Jørgen Peter. Sl. I. R. - 3 - 72. Kastrup, Gram S., Haderslev A.

Jensen, Andreas. Sl. I. R. Husmand, Skovby, Arø.

Jensen, Hans Jørgen. Sl. I. R. III - 2 - 64. Bastrup, Skodborg S., Haderslev A.

Jensen, Iver. Sl. I. R. - Jag. - 134. Heils, Haderslev A.

Jensen, (Hygum), Jørgen. F. I. R. - I - 7 - Hygum, Haderslev A.

Jensen (Haistrup), Niels. Old. I. R. - I - Gr. - Trainkusk Nr. 3. Aftægtsmand, Øsby S. (?), Haderslev A.

Jensen, Nis. F. I. R. Landboelsmand, Høkkelbjerg, Taps S., Haderslev A. 
Jensen, Nicolai Christian. F. I. R. - I-3-123. Ladelund, Tønder A.

Jensen (Thiim), Peter. F. I. R. - I - 1 - 20. Halk, Haderslev A.

Jepsen, Asmus. Sl. I. R. - Gr.-127. Arbejdsmand, Toftlund (?), Haderslev A.

Jessen, Hans. SI. I. R. Gaardmand, Kliplev, Aabenraa A.

Jessen, Jacob. Sl. I. R. - 6 -. Indersteaftægtsmand, Adserballig, Aabenraa A.

Jessen, Jes. Artillerist. Indsidder i Oversø, Flensborg A.

Jessen, Lorentz Andresen kaldet. S1. I. R.-7-15. Bov, Flensborg A.

Jessen, Peter. SI. I. R. - Gr. - 53. Gaardmand, Smedager, Bjolderup S., Aabenraa A.

Jessen, Peter, Sl. I. R. - Gr. -. Nordborg, Aabenraa A.

Jessen, Peter. Sl. I. R. - 3-131. Aller, Haderslev A.

Jochimsen, Iver. Sl. I. R. - 3 - 61. Aftægtsmand, Tabdrup, Bjerning S., Haderslev A.

Johansen, Hans Christian. Sl. I. R. -2-20. Harrislev, Hanved S., Flensborg A.

Johansen, Iver. Sl. I. R. -8- 79. Aftægtsmand, Gestrup Mark, Haderslev A.

Johansen, Johannes. SI. I. R.-7-65. Froslev, Hanved S., Flensborg $\mathbf{A}$.

Johansen (Brandrup), Niels. SI. I. R. -2-64. Aftægtsmand ved Aarøsund, Haderslev $A$.

Johnsen, Lauritz. Sl. I. R. - III - 3-90. Aldersrentenyder, Agerskov, Haderslev A.

Jordansen, Søren. F. I. R. - Jæg. - 38. Arbejdsmand, Styding, Haderslev A.

Juhl, Laue. Sl. I. R. - Jæg. - 132. Sommersted S., Haderslev A.

Juhler, Peter Jensen. SI. I. R. III - Jæg. - 87. Aldersrentenyder, Poghøi, Haderslev A.

Jørgensen, Hans. Baadsmandsmath Nr. 22 af Slesrigs Distrikt (Flensborg). Skovopsynsmand, Lambjerg Skov pr. Sønderborg.

Jørgensen, Hans. Sl. I. R. Halvboelsmand, Skovby, ACrø.

Jørgensen, Hlans. Sl. I. R. -5-116. Boelsaftægtsmand, Dyndved, Aabenraa A.

Jørgensen, Hans. Sl. I. R. - 8 - 60. Husmand, Elstrup, Igen S., Aabenraa A.

Jørgensen (Kolmos), Jens. Sl. I. R. - Jæg. - 68. Boelsmand, Pøl, Aabenraa A. 
Jørgensen, Jens Obrist. F. I. R. - 1 - 46. Grarup, Haderslev A.

Jørgensen, Peter. Sl. I. R. - 2-17. Amtstjener ved Haderslev Amtshus.

Jørgensen, Peter. SI. I. R. Indsidder, Vesterbregninge, A.ro.

Jørgensen, Rasmus. Liv R. R. Kaadbo, Søby, Erø.

Kafton, Ebbe Johan. Sl. I. R. - 1. Indsidder, Rangstrup, Haderslev A.

Kalhauge, Jess. Sl. I. R. - 3 - 75. Oxenvad, Haderslev A.

(Kloppenborg, Jacob. Hansen. Husarcorporal. Afsk. Overvagtmester, Flensborg (?).)

Knudsen, Søren. Sl. I. R. - Jæg. - 29. Kjelstrup, Haderslev A.

Koch, Hans Friedrich. F. I. R. - 3. Arbejdsmand, Stenderup, Nybøl S., Aabenraa A.

Kock, Hans Christensen. Hertuginde Louise Augustas Livjægercorps - 1 -81 (56). Sillerup, Haderslev A.

Kock, Hans Petersen. Sl. I. R. - 154. Ved Sønderborg, Aabenraa A.

Kragh, Mikkel Nielsen. Sl. I. R. - Gr.-26. Rødding, Haderslev A.

Krog, Hans Peter Nielsen. F. I. R. - 5-94. Weistruproi, Haderslev A.

Krogh, Niels. Sl. I. R. - I - 3-38. Rødding, Harlerslev A.

Larsen, Hans. Sl. I. R. Boelsmand, Rise pr. Frøskøbing, સrø.

Larsen, Rasmus. Sl. I. R. - 3-163. Terkelsbøl, Tinglev S., Flensborg A.

Larsen (Flauth), Søren. F. I. R. - II -6-37. Aftægtsmand, Raad, Haderslev A.

Lauritzen, Thomas. Sl. I. R. Husmand, Vesterbregninge, Era.

Lausen, Mikkel. Søindrulleret af Sjæll. Distr. Nr. 224. Aldersrentenyder, Ostorp By, Taps S.

Lorentzen, Hans Peter. Sl. I. R. - Gr.-32. Østerbek, Bov S., Flensborg A.

Lorentzen, Jens. Søindrulleret af Slesv. Distr. Nr. 651. Oevenum paa Føhr.

Lorenzen, Claus. Old. I. R. - III - 1-2. Kaadner og Smed i Kejlskov, Flensborg A.

Lund, Christian. Sl. 1. R. - 3 - 138. Wandling, Starup S., Haderslev A.

Löbner, Anders Johansen. F. I. R. - Gr. -. Bedsted, Aabenraa A. 
Maag, !acob Nissen. Søindrulleret af Slesv. Distr. Nr. 1238. Løit ved Aabenraa.

Madsen, Holden. SI. I. R. - 7 - 157. Lintrup, Haderslev A.

Madsen, Jørgen. F. I. R. - II - Jæg. - 145. Aftægtsmand, Stenderup, Haderslev A.

Marqvard, Adlam Frederik. F. I. R. - 3 - 126. Snedker, Vollerup, Bjolderup S., Aabenraa A.

Mathiesen (Lundorf), Lorentz. SI. I. R. -8-43. Skrydstrup S., Haderslev A.

Mathiesen, Ludvig. Sl. I. R. Aftægtsmand, Arnum, Haderslev A.

Mathiesen, M. Liv R. R. (J. R. l. D.) Bestyrer af Tofte Teglværk, Egernsund, Flensborg A.

Mathisen, Mathias. Sl. I. R. -66 . Borger og Høker i Flensborg.

Michelsen. Thomas Peter. SI. I. R. - Gr. -. Kaadbo, Tranderup, Erø.

Mikkelsen, Casper. Sl. I. R. - Jæg. - 166. Aftægtsmand, Stokkeby, Rise, Frø.

Moltzen, Claus. Old. I. R. - III. - Jæg. - 160. Aftægtsmand i Soltskov, Ste Solt S., Flensborg A.

Mortensen, Jørgen. Sl. I. R. - 1 - 131 . Aftægtsmand, Fjelstrup, Haderslev A.

Mortensen (Ørting), Rasmus. F. I. R. -6 - 40. Pens. Overpolitibetjent, Haderslev.

Maller, Andreas Nicolai. Sl. I. R. - 3 -. Arbejdsmand, Skjærbæk, Haderslev A.

Møller, Jørgen Clausen. SI. I. R. - 3-58. Skrydstrup S., Haderslev A.

Nicolaysen, Hans. Holst. I. R. - I - 5 - 26. Abild, Tønder A.

Nicolaisen (Hyrup), Hans. Sl. I. R. - Gr. - 45. Aftægtsmand, Øsby S. (?), Haderslev A.

Nielsen (Gram), Anders. Sl. I. R. - Gr. - 42. Brøns, Haderslev A.

Nielsen, Andreas, Sl. I. R. Stenderup, IIaderslev A.

Nielsen (Streling), Frantz. F. I. R. - II - Jæg. - 143. Ellund, Hanved S., Flensborg A.

Nielsen, Friedrich. Sl. I. R. - 8 - 45. Harrislev, Hanved S., Flensborg A.

Nielsen, Hermann. Sl. I. R. - Jæg. - 106. Haderslev.

Nielsen, Klaus. Sl. I. R. - Jæg. - 45. Fohl Fattighus, adl. Gods Gram.

Nielsen (Bundgaard), Peter. F. R. 1. D.-2-99 (166). Arbejdsmand, Halk, Haderslev A. 
Nissen (Tombøl), Ilans. F. I. R. - 7-115 (Oc. 9). AftægtsGaardejer, Felsted, Aabenraa A.

Nissen, Mathias. Sl. I. R. - I -. Indsidder i Oversø, Flensborg A.

Nissen, Peter. Sl. I. R. $-4-153$. Sophiendal, Tinglev S., Flensborg A.

Nissen, Wilken. Sl. I. R. - Gr. -. Aftægtsmand, Ørdrup, Haderslev A.

Ohlsen, Gabriel Heinrich. Old. I. R.-6-1. Rathsdiener i Flensborg.

Olsen, Knud Albertsen. Slesv. R. R.-1-28. Aftægtsmand, Stokkeby, Rise, Erø.

Olufsen, Jørgen. Holst. I. R. - Jæg. - Stykkusk. Arbejdsmand, Lygumkloster, Tønder A.

Owesen, Hans. Holst. Art. Brig. - 16 - 79. Gaardejer-Aftægtsmand, Hyrup, Flensborg A.

Paag (Ørby), Søren Petersen. F. I. R. - I - 1-143. Aftagtsmand, Aarø, Haderslev A.

Pedersen, Niels. Sl. I. R. - I - 4 - 76. Aalkjær, Gram Gods.

Pedersen, Niels, J. Sk. C.. Nørbye Vilstrup, Haderslev A.

Pedersen, Peder. sl. I. R. -8-114. Brosbøl, Starup S., Haderslev A.

Pedersen (Fløystrup), Peder. Holst. R. H. -4-42 (43). Drendrup Mark, Ødis S., Haderslev A.

Pedersen (Süderbek), Peder. F. I. R. -6-97. Aftægtsmand, Porsplet, Haderslev A.

Pedersen, Thomas. Sl. I. R. - 4 - 54. Indsidder, Stokkeby, Rise, Erø.

Petersen, Bonke. S!. 1. R. - Gr. - 52. Syderdize pr. Emmesbøl, Tønder A.

Petersen (Paulsen), Christian Hansen. Holst. R. IR. Skomager i Broager.

Petersen, IIans. Sl. I. R. $-f-$. Fæsted, Hygum S., Haderslev A.

Petersen, Hans Christian. Sl. I. R.--Jæg.-60. Skræder, Dyndvad By, Igen S., Aabenraa A.

Petersen, Jens. Sl. I. R. - III - 2-94. Mohrbæk, Aabenraa A. Petersen, Jes. Sl. I. R. - 1 - 128. Inderste, Guderup, Igen S., Aabenraa A.

Petersen (Thorsmark), John. Sl. I. R. - I - 5. Aftægtsmand, Baulund Nymark, Haderslev A.

I'etersen, Knud. Sl. I. R. - 20 (89). Háderslev. 
Petersen, Mathias Jensen. Sl. I. R. - I-3-145. Drawit Skovfogedbolig pr. Lygumkloster, Tønder A.

P'etersen, Nicolai. Sl. I. R. - 4-83. Smed, Haderslev.

Petersen, Nis. F. I. R.-2-. Bjendrup, Steppinge S., Haderslev A.

Petersen, Niels Præstegaard. Sl. I. R.-Jæg.-128. Grarup, Haderslev A.

Petersen, Peter. Batt. Gerstenberg - 17 -. Arbejdsmand.i D. Krackes Enkes Sukkerraffinaderi, Flensborg.

Petersen, Peter. Sl. I. R. - 6 -. Kaadner og Kromand i Frgrup, Oversø, Flensborg A.

Petersen (Stiftsgaard), Peter. Befaren af Slesv. Distr. Nr. 248.

Philipsen, Andreas. Sl. I. R. Aftægtsmand i Oxager Vesterskov, Husby S., Flensborg A.

Poulsen (Basse), Poul. Helbefaren af Slesv. Distr. Nr. 936. Løit ved Aabenraa.

Quars, Hans Christian Petersen. Batt. Friis-17-30. Harrislev, Hanved S., Flensborg A.

Quars, Nicolai Petersen. Sl. I. R. - 2-148. Bov, Flensborg A. Rasmussen, Claus. Sl. I. R. - 4 -. Husmand, Tranderup, Erø.

Rasmussen, Jens. F. R. l. D. Aftægtsmand, Tranderup, Arø.

Rasmussen (Holbæk), Matthias. F. I. R. -5 - 105. Tyrstrup, Haderslev A.

Rasmussen, Michael. F. I. R. -7. Afsk. Sergeant og Overpolitibetjent, Flensborg.

Rasmussen, Niels. Sl. I. R. - 8-92. Skrydstrup S., Haderslev $A$.

Rasmussen, Rasmus. F. I. R. - 1-99. Murersvend i Haderslev.

Rotz, Nicolai. Sl. I. R. - Gr. - Indsidder, Jaruplund, Oversø S., Flensborg A.

Schmidt, Anders Svendsen. Sl. I. R. - II - 6 - 73. Østergasse i Skjærbæk S., Haderslev A.

Schmidt, Hans Andersen. SI. I. R. - III - 4 - 159. Kaadner, Lygumkloster, Aabenraa A.

Schmidt, Morten Petersen. Sl. I. R. - 8 - 87. Landboelsmand, Rørkier i Bierning S., Haderslev A.

Schrøder, Christian Frederik. Sl. I. R.-8-68. Husejer i Nordborg, Aabenraa A.

Siewers, Claus. Old. I. R. - 7-114. Skibstømmermand, Nübbel i Hohn S., Hütten A. (Aabenraa A.). 
v. Simesen, Søren. Ilolst. R. R. - 3 - Premierlt. og Cmdr. +161 1858. Pens. Major, Haderslev.

Snooer, IIans. Sl. I. R. $-7-118$. Sommersted S., Haderslev $A$.

Snooer, Laue. Sl. I. R. - $\boldsymbol{\gamma}-97$. Indsidder, Errigsted, Bierning S., Haderslev A.

Sommer, Peter Christian. Sl. J. C. - II - 1 - 155. Flensborg A.

Sørensen. Hans. Sl. I. R. - Jæg.-108. Murersvend i Haderslev.

Sørensen, Jens. Sl. I. IR. - Jag. - 119. Brosbøl i Starup S., Haderslev A.

Sørensen, Lars. Sl. I. R. - 8-25. Indsidder, Skovbølling, Bierning S., Haderslev A.

Sørensen (Lund) (Tiirslund), Noa. F. I. R. - II-6-47. Aftægtsmand, Øsby, Haderslev A.

Sørensen, Peder. Artillerist. Oxenvad, Haderslev A.

Thaisen, Mathias. Sl. I. R. - II - 7 - 34. Aftægtsmand, Styding, Haderslev A.

Thaysen, Hans. Sl. I. R. - 5 - 24 (157). Inderste i Traasbøl, Felsted S., Aabenraa A.

Thoisen, Christian. Hertuginde Louise Augustas Livjægercorps-2 - 53. Aftagtsmand i Stenderup, Nybøl S., Aabenraa A.

Thomsen, Hans. Sl. I. R. Fjerdingboelsmand, Vaarbjerg, Ærø.

Thomsen, IIans Friedrich. Sl. J. C. $-2-138$. Frøslevmark, Hanved S., Flensborg A.

Thomsen, Hans Holgersen. Sl. I. R. - 2 - 150. Husmand, Elstrup, Aabenraa A.

Thomsen, Jens. Søindrulleret af Slesv. Distr. Nr. 469. Keitum paa Sylt.

Thomsen, Peter. Stenhugger, Sdr. Smedeby, Siversted S., Flensborg A.

Thomsen, Simon. Sl. I. R. - I-1-97. Halk, Haderslev A. Thomsen, Thomas. Sl. I. R. - 2 -38. Hygum, Haderslev A. Tofft, Jørgen. Sl. I. R. - 7 -. Ulstrup, Vedsted S., Haderslev A.

Toft, Jens Christian. Sl. I. R. -4 -. Aftegtsmand, Gøtterup, Haderslev A.

Torvelsen, Torvel. Old. I. R. - Stykkusk. Aftægtsparcellist, Østerholm, Aabenraa A.

Trip, Iver. Sl. I. R. $(-3-\tau \tau)$ - III - 4 - 9. Arbejdsmand i Lygumkloster, Aabenraa A. 
Sønderjydske Veteraner fra Napoleonskrigene. 119

Tychsen, Rasmus. Sl. I. R. - Jag. - 64. Langbjerg, Hanved S., Flensborg A.

Varsøe. Hans Niels. Sl. I. R. - 160 (104). Vilstrup, Haderslev $\mathrm{A}$.

Vilhelmsen, Søren. Sl. I. R. Husejer, Tingskovhede, Taps, Haderslev A.

Villarlsen (Farsted), Mikkel. F. I. R. - I-7-. Hygum, Haderslev A.

Walbom, Hans l'eter. Sl. I. R. - 6 - 30. Aftægtsmand, Gjenner, Aabenraa A.

Wind, Jørgen Jespersen (Jensen). Holst. rid. Art. - 3 -. Aftegtsmand, Rangstrup, Haderslev A.

Witzen, Jes (Hansen). Søindrulleret af Slesv. Distr. Nr. 1236. Løit ved Aabenraa.

Ostergaard, Marcus. Sl. I. R. - III - 3-79. Sognefoged og Gaardmand, Birkelev, Haderslev A. 